\title{
A study of Stature Appraisal from the length of Little Finger of the Population of Uttar Pradesh
}

\author{
Manisha, Amit Chauhan* and S K Shukla \\ Amity Institute of Forensic Sciences, Amity University, India
}

Submission: December 18, 2017; Published: January 04, 2018

*Corresponding author: Amit Chauhan, Amity Institute of Forensic Sciences, Amity University, India; Tel: 91-9540067484;

Email: amit_chauhan777@yahoo.in

\begin{abstract}
In today's developmental era of technology, identification of an individual has become one of the most important aspects of investigation as well as identity in our civilization. The advance technologies have taken over the traditional analytical methods, even still, some of the aspects are left questionable for establishing identity of suspects from the minutiae details which can reveal or provide the clue about the culprit/ suspect involved in omission of act. In forensic investigation, minutiae details/ clue of victim left over the crime scene are sufficient to disclose the identity of victim/suspect. These details need a careful analysis/ intensification which are left over any surface or objects unknowingly while in some cases where the unidentified dead bodies are recovered from the crime scene, the Skelton remains could provide the details such as the stature, gender and age of the victim. Distinguish scientists came out with innovative technology and methods to study these remains and give their contribution by establishing new parameters of identification. In this present study, we studied the little finger length to determine the stature and for gender discrimination of age group 18-25 years from the population of National capital region of India and successfully concluded that the suspect can be nabbed from the intensified little finger length or Skelton remaining that are encountered during the investigation of several types of cases.
\end{abstract}

Keywords: Chronic Prostatitis; Relapses; Recurrent Uti; Biofilm ;Antimicrobial Therapy

\section{Introduction}

The modern era of advancement and digital technology has facilitated the identification of an individual for various aspects such as, national identity, gender, age, profession or any criminal record or involvement in any conspiracy etc $[1,2]$. Investigators often experience some problematic situations in the identification of people which may be cause of natural disasters such as floods, hurricanes, earth-quake tsunami, or in cases of explosion, plane crash etc. Excessive complications are faced in the burnt dead bodies where only remnants are recovered [35]. In Anthropology, investigator deals with the bones remnants to extract out the information about an individual from them [6]. Personal identification of an individual is based on the uniqueness records or multiple consistent features i.e. tattoo marks, birth mark, injury marks etc. that become very important for any forensic expert/ medico-legal officer to turn it out with responsibility in any investigation [7]. In anthropology, the investigators personal deal with the Skelton remains or bones to estimate about the gender, age, stature etc [8].

Strategies to decide stature make presumptions about extents of the human body. This is especially the case for relapse strategies, which force a straightforward relationship between the measure of a particular bone and stature [9]. There is diverse arrangement of formulae for different gatherings and populace. Gender estimation is based on the morphological features of pelvis and skull because of conceptive necessities indicates distinctive characteristics elements $[10,11]$. These morphological features of skeletal remains help to discriminate, that is, the incidence of non-metric traits on each of the bone. For example, these features include the degree of fusion of the proximal and distal epiphyses, fusion of the cranial sutures, dental eruption patterns etc $[12,13]$.

A numerous methods are used by forensic anthropologists to estimate the age at death from remnants by using of a correlation, regression equations which provide assistance in estimating other physical attributes like structure to get aid in the identification of victim $[14,15]$. In the previous studies conducted by scientists \& researchers, it was observed that a proportions of body segment vary between the population of one place from other place which may be a cause of metamorphosis in environment, occupation etc [16]. Because of different body parts response differently and ripen change in environmental conditions as well as genetics [17].

Assorted studies have been carried out by many researchers to establish a relation between the height/ stature with gender. This study was conducted by using the little finger length of both of hands as a parameter of the population of National capital 
region of India. The researchers were incapable to ascertain the stature and gender of the defunct accurately by use of some statistical equations for completion of this study [18]. The results of this study can be used by forensic anthropologists like other investigative techniques which will standardized and worldwide acceptable for investigation [19].

\section{Methodology}

This study was focused on the stature assessment and the gender discrimination from the little finger length of the population of national capital region of India. All the samples were collected from the North-East district of Delhi and Yamuna Vihar of Delhi, Barout, Ramala, Sarurpur of Distrcit Baghpat. The purpose of this study was to establish the degree of reliability for the identification perseverance.

\section{Materials and Method}

For this study, 100 individuals including 50 males and 50 females from the age group of 18-25 years were selected and studied. Sample selection was done randomly and the consent of the subjects was taken prior by explaining the purpose of this study. All the subjects included in the present study were healthy and had no history of any sort of deformity of the hand, metabolic disorders and any developmental process. To avoid any kind of diurnal variation, all the measurements were taken during day time interval. All the measurement was taken with the help of anthropometric board. Measurements of stature were taken as vertical distance from the vertex to the foot.

To measure the stature, all the subjects were asked to stand barefoot on the platform of stadiometer with the upper back, and heels pressed against the wall thus ensuring their upright position, while head was positioned in the Frankfurt horizontal plane. During the measurement of little finger length, all the subjects were asked to turn inverse their palm \& fingers horizontally towards the stand following by the Frankfurt plane Table 1: Data of both genders according to age and the measurements of right-hand and left-hand little fingers.

\begin{tabular}{|c|c|c|c|c|c|c|}
\hline Serial no. & Age & $\begin{array}{c}\text { Right hand } \\
\text { little finger } \\
\text { measurement }\end{array}$ & $\begin{array}{l}\text { Left hand } \\
\text { little finger } \\
\text { measurement }\end{array}$ & Age & $\begin{array}{l}\text { Right hand } \\
\text { little finger } \\
\text { measurement }\end{array}$ & $\begin{array}{c}\text { Left hand } \\
\text { little finger } \\
\text { measurement }\end{array}$ \\
\hline \multicolumn{4}{|c|}{ Female subject's data } & \multicolumn{3}{|c|}{ Male subject's data } \\
\hline 1. & 25 & 7.5 & 7.6 & 25 & 7.5 & 7.4 \\
\hline 2. & 25 & 8.4 & 8.5 & 25 & 7 & 7.1 \\
\hline 3. & 24 & 8.4 & 8.2 & 24 & 8 & 7.6 \\
\hline 4. & 22 & 7.5 & 7.6 & 23 & 7.3 & 7.4 \\
\hline 5. & 25 & 7.6 & 7.7 & 24 & 7.3 & 7.2 \\
\hline 6. & 25 & 8.1 & 8.2 & 24 & 7.5 & 7.5 \\
\hline 7. & 23 & 7.9 & 7.9 & 23 & 8.1 & 8 \\
\hline 8. & 24 & 7.7 & 7.8 & 24 & 8 & 7.9 \\
\hline 9. & 24 & 8.6 & 8.6 & 22 & 7.5 & 7.6 \\
\hline 10. & 23 & 7.9 & 8 & 24 & 7.5 & 7.5 \\
\hline 11. & 23 & 8.5 & 8.6 & 23 & 8 & 7.6 \\
\hline
\end{tabular}

[20]. The movable rod of stadiometer was brought in contact with vertex in the mid-sagittal plane. All the measurements of thumb were measured with the help of a sliding calliper, when the subjects placed their hands supine on a flat horizontal surface with the fingers extended [21]. The measurement of little finger length was obtained up to one decimal place and avoid any kind of error, all the measurements were taken twice and the average both of measures were considered for the further analysis. oid any kind of instrumental error or variation, all the $\pm 0.01 \mathrm{~cm}$ was observed.

\section{Statistical Analysis}

The data was tabulated, analyzed and subjected to statistical analysis by using SPSS software (latest version, 11.0).

\section{Result and Discussion}

To calculate out the height of an individual, bones especially long bones are preferable in practice because of their higher correlation coefficient and small error of to estimate the stature. However, the difficulties arise in that condition where only dissect body parts are available for medical examination and further analysis. Hence, forensic investigators are exploring new parameters and establishing new methods to estimate the stature, gender discrimination by the measurements of head, foot, face, finger lengths, phalanges etc. As described earlier, to conduct this study a data of hundred subjects (including male \& female) were collected by taking their respective measurements. These measurements are given below in Table 1. The dossier of measured subjects right hand and left- hand little finger length is described in the given table according to their respective age. Since $\mathrm{p}$ is greater than 0.005 it is significant. The correlation coefficient in the measurement of right hand little finger was 0.289 at significant level while in left hand, it was 0.297 (Tables 2 \& 3). 


\section{Journal of Forensic Sciences \& Criminal Investigation}

\begin{tabular}{|c|c|c|c|c|c|c|}
\hline 12. & 22 & 8.2 & 8.3 & 24 & 7.8 & 7.9 \\
\hline 13. & 23 & 8.1 & 8 & 24 & 8.1 & 8 \\
\hline 14. & 23 & 8.3 & 8.5 & 24 & 8 & 7.5 \\
\hline 15. & 23 & 8.9 & 8.8 & 23 & 7 & 7 \\
\hline 16. & 25 & 8.3 & 8.3 & 23 & 8 & 7.8 \\
\hline 17. & 25 & 8.5 & 8.7 & 22 & 7.3 & 7.4 \\
\hline 18. & 25 & 8.5 & 8.5 & 24 & 8.4 & 8.1 \\
\hline 19. & 22 & 9.3 & 9.3 & 21 & 7.1 & 7.3 \\
\hline 20. & 25 & 7.9 & 8.1 & 24 & 8 & 7.4 \\
\hline 21. & 25 & 7.6 & 7.6 & 25 & 7.5 & 7.5 \\
\hline 22. & 21 & 8.4 & 8.5 & 24 & 7.7 & 7.6 \\
\hline 23. & 20 & 8.1 & 8.1 & 21 & 8 & 7.9 \\
\hline 24. & 20 & 8.4 & 8.5 & 24 & 8.1 & 8.1 \\
\hline 25. & 25 & 8.9 & 8.8 & 25 & 7.1 & 7.2 \\
\hline 26. & 24 & 8.5 & 8.5 & 23 & 7.2 & 7.4 \\
\hline 27. & 24 & 8 & 8 & 23 & 7.4 & 7.6 \\
\hline 28. & 23 & 8.6 & 8.5 & 23 & 8 & 7.7 \\
\hline 29. & 24 & 8.6 & 9.1 & 23 & 7 & 6.5 \\
\hline 30. & 23 & 8.3 & 8.1 & 23 & 7.2 & 7.2 \\
\hline 31. & 19 & 9 & 9.2 & 20 & 7.7 & 7.8 \\
\hline 32. & 20 & 8.1 & 8.5 & 22 & 7.6 & 7.6 \\
\hline 33. & 20 & 8.5 & 8.9 & 23 & 7.4 & 7.9 \\
\hline 34. & 24 & 8.7 & 8.8 & 24 & 7.7 & 7.6 \\
\hline 35. & 23 & 9 & 8.6 & 25 & 8 & 8 \\
\hline 36. & 24 & 8.5 & 8.2 & 25 & 7.5 & 7.4 \\
\hline 37. & 25 & 8 & 8.2 & 22 & 7.7 & 7.6 \\
\hline 38. & 25 & 8.5 & 8.4 & 21 & 7.9 & 8.2 \\
\hline 39. & 23 & 8.4 & 8.5 & 20 & 7 & 6.8 \\
\hline 40. & 23 & 8.9 & 8.8 & 20 & 7.5 & 7.4 \\
\hline 41. & 23 & 8.5 & 8.2 & 20 & 7.9 & 8.2 \\
\hline 42. & 24 & 8 & 8.2 & 21 & 7 & 6.8 \\
\hline 43. & 20 & 8.5 & 8.1 & 24 & 8 & 8.1 \\
\hline 44. & 20 & 8.8 & 9 & 23 & 7.8 & 8 \\
\hline 45. & 21 & 8.6 & 8.1 & 23 & 7.2 & 7.1 \\
\hline 46. & 21 & 9.2 & 9.2 & 23 & 7.5 & 7.4 \\
\hline 47. & 23 & 8.2 & 8.4 & 25 & 8.5 & 8.1 \\
\hline 48. & 25 & 7.6 & 7.7 & 25 & 7.5 & 7.2 \\
\hline 49. & 24 & 7.5 & 7.5 & 21 & 8.1 & 8.2 \\
\hline 50. & 23 & 6.8 & 7 & 24 & 7.5 & 7.3 \\
\hline
\end{tabular}

Table 2: Pearson correlation coefficient of little finger measurements with stature and $p$ value in females.

\begin{tabular}{|l|c|c|c|c|c|}
\hline \multicolumn{2}{|c|}{ Right Hand } & \multicolumn{2}{c|}{ Left hand } \\
\hline thumb & Correlation coefficient & p value & thumb & Correlation coefficient & p value \\
\hline & 0.289 & $<0.001$ & & 0.297 & $<0.001$ \\
\hline
\end{tabular}




\section{Journal of Forensic Sciences \& Criminal Investigation}

Table 3: Pearson correlation coefficient of thumb measurements with stature and p value in males.

\begin{tabular}{|c|c|c|c|c|c|}
\hline \multicolumn{3}{|c|}{ Right thumb } & \multicolumn{2}{c|}{ Left thumb } \\
\hline Thumb & $\begin{array}{c}\text { Correlation } \\
\text { coefficient }\end{array}$ & p value & Thumb & $\begin{array}{c}\text { Correlation } \\
\text { coefficient }\end{array}$ & 0.159 \\
\hline & 0.173 & $<0.001$ & & $<0.001$ \\
\hline
\end{tabular}

The regression equation for stature estimation was applied in both of gender (male as well as female). The stature estimation of females is shown in Table 4 below while the male stature estimation regression equation is shown in Table 5 below. The regression coefficient estimation for females is given below in Table 6. The regression coefficient estimation for females is given below in Table 7. For correlation coefficient for right hand little finger in females we used the regression coefficient

Table 4: Regression equation for estimation of stature in females.

\begin{tabular}{|c|c|c|c|}
\hline \multicolumn{2}{|c|}{ Right hand } & \multicolumn{2}{c|}{ Left hand } \\
\hline Thumb & $\begin{array}{c}\text { Height }= \\
106.71+6.42\end{array}$ & Thumb & $\begin{array}{c}\text { Height }= \\
114.61+7.00\end{array}$ \\
\hline
\end{tabular}

Table 5: Regression equation for estimation of stature in males.

\begin{tabular}{|l|c|c|c|}
\hline \multicolumn{2}{|c|}{ Right hand } & \multicolumn{2}{c|}{ Left hand } \\
\hline & Height $=$ & & Height $=$ \\
Thumb & $104.226+$ & Thumb & $129.753+$ \\
& 9.432 & & 5.707 \\
\hline
\end{tabular}

Table 6: Regression coefficient estimation for females.

\begin{tabular}{|c|c|c|}
\hline Fingers (thumb) & Constant in $\mathbf{c m}\left(\mathrm{b}_{\mathrm{o}}\right)$ & $\begin{array}{c}\text { Regression } \\
\text { coefficient in } \mathrm{cm} \\
\left(\mathrm{b}_{1}\right)\end{array}$ \\
\hline Right thumb & 116.71 & 6.42 \\
\hline Left thumb & 112.61 & 7.00 \\
\hline
\end{tabular}

Table 7: Regression coefficient estimation for males.

\begin{tabular}{|c|c|c|}
\hline Fingers (thumb) & Constant in $\mathbf{c m} \mathbf{( b}_{\mathbf{o}}$ ) & $\begin{array}{c}\text { Regression } \\
\text { coefficient in } \mathbf{~ c m} \\
\mathbf{( b}_{\mathbf{1}} \text { ) }\end{array}$ \\
\hline Right thumb & 104.22 & 9.43 \\
\hline Left thumb & 129.75 & 5.70 \\
\hline
\end{tabular}

$Y=\left(b_{0}+b_{1}\right) x$

For right -hand little finger measurements in male.

$y=B 0+B 1 x$

$B 0=104.22$

$B 1=9.43$

$x=7$

$y=104.22+57.98+162.2$

Measured height $=163.1 \mathrm{~cm}$

To estimate the stature, linear regression equation derived from the little finger length shows a significant statistically $(p<0.001)$ relationship between them. As of resultant from the derived regression models in the present study, the standard error in stature estimation was more in males than the females. In other words, the accuracy of stature estimation in females is higher than males. According to our study height and length of the hand were significantly more in males compared to females. There was no bilateral variation of right and left little fingers length.

\section{Conclusion}

Since very early of time, stature estimation and gender discrimination from the skelton remains have been used for the identification of an individual but a very few work exists about the gender discrimination and stature estimation from the little finger length. As a resultant of this study, it was observed that little finger length is a good and reliable method for gender discrimination and stature estimation which raised hopes that even a Skelton remains of little finger can conclude the identity of suspect/victim. Every year around 2,22,446 dead bodies are recovered and among them only 5\% are found in appropriate condition while rest are found in decomposed, putrefied or Skelton form. In such cases, when the identity of actual person wouldn't possible then stature estimation along with gender identification and age determination helps to conclude the case. This study will help the investigators to collect information about victim around the particular area while minimize the time duration of investigation. It could be proved as a milestone for justice system in the population of National Capital Region.

\section{References}

1. Tyagi AK, Kohli A, Verma SK, Aggarwal BB (1999) Correlation between stature and finger Length. International Journal of Medical Toxicology and Legal Medicine 1: 20-22.

2. Rastogi P, Kanchan T, Menezes RG, Yoganarasimha (2009) Middle finger length-a predictor of stature in the Indian population. Med Sci Law 49(2): 123-126.

3. Athwale MC (1963) Estimation of height from length of forearm bones. A study on 100 Maharashtrian male adults of age 25-30. American Journal of Physical Anthropology 21: 105-112.

4. Begum E (1999) Estimation of Stature from Hand Measurements in Assamese Muslims. Bulletin of Department of Anthropology, University of Guwahati, Assam, India.

5. Bhatnagar DP, Thapar SP, Batish MK (1987) Identification of personal height from somatometery of hands in the Punjabi males 24(2): 137141 .

6. Rani M, Tyagi AK, Ranga VK, Rani Y, Murari A (2011) stature estimates from foot dimensions. JPAFMAT 11(1).

7. Jasuja OP, Singh G (2004) Estimation of stature from hand and phalange length. JIAFM 26(3): 1-7.

8. Giles E, Vallandigham PH (1991) Height Estimation from Foot and Shoe print length. Journal ofForensic Sciences 36(4): 1134-1151.

9. Jasuja OP, Singh J, Jain M (1991) Estimation of stature from foot and shoe measurements bymultiplication factors: A reviewed attempt. Forensic Science International 50: 203-215. 
10. Jasuja OP, Manjula (1993) Estimation of stature from footstep length Forensic Science International 61: 1-5.

11. Jasuja OP, Harbhajan S, Anupama K (1997) Estimation of stature from stride length while walking fast. Forensic Science International 86: 181-186.

12. Kapoor AK (1987) Estimation of stature from hand length as obtained through palm prints among the Lodhas of district Midnapur, West Bengal. Indian Journal of Physical Anthropology 13: 139.

13. Lal CS, Lala JK (1972) Estimation of stature from tibial and ulnar lengths in North Bihar. Journal of Medical Association 58: 120-121.

14. Patel MP, Joshi NB, Dongre AV (1964) Regression equation of height on tibial length. Indian Journal of Medical Research 52: 531- 534.

15. Pearson K (1899) Mathematical contributions to the theory of evolution V: On the reconstruction of stature of pre-historic races. Philosophical Transection of Royal Society; London 192: 169-224.

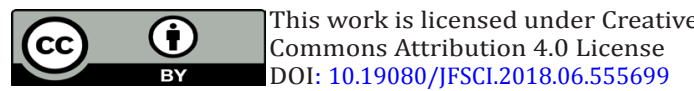

16. Saxena SK (1984) Study of correlations and estimation of stature from hand length, hand breadth and sole length. Anthropol Anz 42(4): 271 276.

17. Sharma PK, Kapoor AK (2001) Estimation of stature from fingertip length and finger print tiplength among criminals, Recent advances in forensic biology (edited), Kamla-RajPublishers 117-127.

18. Shintaku K, Furuya Y (1990) Estimation of stature based on the proximal phalangeal length ofJapanese women's hands. JUEOH 12(2): 215-219.

19. Thakur SD, Rai KS (1987) Determination of Stature from hand measurement, Medicine Science and Law 78: 25-28.

20. Trotter M, Glesser GC (1952) Estimation of stature from long bones of American White andNegroes. American Journal of Physical Anthropology 10: 463-514.

21. Baul S (1974) Anatomical Clinical Study of Human foot. M.S. Thesis Punjabi University, Patiala, India.

\section{Your next submission with Juniper Publishers will reach you the below assets}

- Quality Editorial service

- Swift Peer Review

- Reprints availability

- E-prints Service

- Manuscript Podcast for convenient understanding

- Global attainment for your research

- Manuscript accessibility in different formats

( Pdf, E-pub, Full Text, Audio)

- Unceasing customer service

Track the below URL for one-step submission https://juniperpublishers.com/online-submission.php 